\title{
Bovine Oocytes Grown in Serum-Free Medium Acquire Fertilization Competence
}

\author{
Shoichiro SENBON1), Yoshiyuki FUKUMI'), Atsushi HAMAWAKI ${ }^{3)}$, \\ Motoichi YOSHIKAWA ${ }^{3)}$ and Takashi MIYANO ${ }^{4)}$
}

${ }^{1)}$ Graduate School of Science and Technology, Kobe University, Kobe 657-8501,

${ }^{2)}$ Tokushima Prefectural Agriculture, Forestry and Fisheries Technology Center, Itano, Tokushima 771-1310, ${ }^{3)}$ Animal Bio-Technology Center Kobe, Livestock Improvement Association of Japan, Kobe 653-0032, ${ }^{4}$ Laboratory of Reproductive Biology and

Biotechnology, Faculty of Agriculture, Kobe University, Kobe 657-8501, Japan

\begin{abstract}
We previously found that bovine oocytes $90-99 \mu \mathrm{m}$ in diameter in early antral follicles grew to nearly their final size in serum-free medium, with some of the oocytes acquiring the nuclear competence to reach the second metaphase. In the present study, we examined the competence of the fertilization and pre-implantational development of the oocytes grown in serum-free medium. Bovine early antral follicles, $0.4-0.7 \mathrm{~mm}$ in diameter, were collected mechanically using fine forceps, embedded in collagen gels, and cultured in serum-free medium for 16 days. Grown oocytes which were enclosed by granulosa cells and did not show disintegrated ooplasm were recovered as normal oocytes, were transferred to the maturation medium, and then inseminated with spermatozoa. Ten to $12 \mathrm{~h}$ after insemination, $28 \%(41 / 145)$ of the oocytes were penetrated by spermatozoa. Of the penetrated oocytes, $18(12 \%)$ formed a female and a male pronuclei, and $10(7 \%)$ had a female pronucleus and an enlarged sperm head. Among the abnormally penetrated oocytes (13/41), 10 were penetrated by multiple spermatozoa and 3 were penetrated by a spermatozoon at the first metaphase stage. Of the 106 inseminated oocytes grown under serum-free conditions, 8 oocytes had cleaved and developed to the 2-cell stage $48 \mathrm{~h}$ after insemination, and 3-4-cell embryos and 5-8-cell embryos were observed after 72-96 h. However, no embryo developed to the blastocyst stage within 8 days. These results indicate that bovine oocytes grown in serum-free medium can be fertilized, but acquire insufficient embryonic development competence under the employed culture conditions.
\end{abstract}

Key words: Cow, Embryonic development, Fertilization, In vitro-grown oocyte, Serum-free medium

(J. Reprod. Dev. 50: 541-547, 2004)

$\mathbf{R}$ esearchers have attempted to use non-growing and growing oocytes in bovine ovaries as a source of mature eggs. Yamamoto et al. (1999) have successfully produced a calf from bovine growing oocytes collected from early antral follicles and have suggested that growing oocytes maturing in bovine ovaries were capable of being fertilized and developing to term by artificially growing up them

Accepted for publication: May 18, 2004

Correspondence: T. Miyano (e-mail: miyano@kobe-u.ac.jp)
[1]. In their study, oocyte-cumulus granulosa cell complexes were collected from early antral follicles in bovine ovaries, embedded in collagen gels, and cultured in medium containing serum for 14 days. Recently, in an easier culture system in which oocyte-cumulus granulosa cell complexes were cultured on flat substratum, oocytes in the complexes grew and acquired maturation, fertilization, and embryo developmental competence [2]. In both studies, serum- 
supplemented medium was used as the growth culture medium.

Serum is a complex mixture of many small and large biomolecules with physiologically balanced growth-promoting and growth-inhibiting activities [3]. Some of the components have been found to maintain viability and to stimulate the growth of many kinds of mammalian cells in culture. Serum may stimulate the proliferation and differentiation of oocyte-surrounding somatic cells, granulosa cells, and theca cells in vitro. However, serum has some disadvantages [4]. It includes a variety of proteins and small molecules, which must be systematically eliminated if we want to examine the effects of each factor contained in serum, even in trace amounts.

Serum-supplemented medium has been used for growth culture of oocytes from domestic species, such as cow $[1,2,5]$, pigs [6] and sheep [7, 8], but some reports have indicated that oocytes are able to survive and grow in serum-free medium. Bovine secondary follicles cultured in serum-free medium form an antrum after 10 days, and maintain their viability after 28 days [9]. Moreover, when secondary follicles isolated from frozen thawed sheep ovarian tissue were cultured in serum-free medium supplemented with gonadotropins, they survived and developed to the antral stage after culture of 30 days [10]. Among the cultured follicles, the oocytes $78 \mu \mathrm{m}$ in mean diameter before culture eventually grew to $131 \mu \mathrm{m}$, which is the final size in sheep. These reports have demonstrated that domestic animals' follicles and oocytes in the follicles can survive under serumfree conditions for a long period, but the maturational and fertilizable competence of the oocytes have not yet been examined. We previously found that bovine oocytes grown in serum-free medium for 16 days acquire the meiotic competence to undergo germinal vesicle breakdown and to reach the second metaphase (MII) [11]. In the present study, we examined their competence regarding fertilization and subsequent in vitro development.

\section{Materials and Methods}

\section{Growth and maturation culture of bovine oocytes}

The method for growth and maturation culture of bovine growing oocytes was based on the method described by Senbon et al. [11]. Briefly, bovine early antral follicles $0.4-0.7 \mathrm{~mm}$ in diameter were dissected from the ovarian cortex using fine surgical blades and forceps. Groups of 15-20 early antral follicles were embedded in collagen gels (Cellmatrix Type I-A, Nitta Gelatin Inc., Osaka, Japan) and cultured at $38.5 \mathrm{C}$ in a humidified atmosphere of $5 \% \mathrm{CO}_{2}$ and $95 \%$ air for 16 days. The culture medium was TCM199 containing $2.2 \mathrm{mg} /$ $\mathrm{ml} \mathrm{NaHCO}, 0.08 \mathrm{mg} / \mathrm{ml}$ kanamycin, $0.1 \mathrm{mg} / \mathrm{ml}$ sodium pyruvate, $4 \mathrm{mM}$ hypoxanthine (Sigma, St. Luis, USA), and $3 \mathrm{mg} / \mathrm{ml}$ bovine serum albumin (BSA, International Regents Corporation, Kobe, Japan). After the growth culture, the gels and follicles were torn with fine forceps, and the oocytes were recovered. Some oocytes were been entirely denuded, and others were enclosed by granulosa cells. Granulosa cell-enclosed oocytes with disintegrated ooplasm and denuded oocytes were discarded. Granulosa cell-enclosed oocytes showing normal morphology were considered as surviving oocytes. The diameters of the oocytes (excluding the zona pellucida) were measured and then they were further cultured individually in 10$\mu$ drops of the maturation medium, TCM199 containing $2.2 \mathrm{mg} / \mathrm{ml} \mathrm{NaHCO}{ }_{3}, 0.08 \mathrm{mg} / \mathrm{ml}$ kanamycin, $0.1 \mathrm{mg} / \mathrm{ml}$ sodium pyruvate, and $10 \%$ fetal calf serum (FCS, Dainippon Pharmaceutical Co. Ltd., Osaka, Japan) for $24 \mathrm{~h}$ at $38.5 \mathrm{C}$ in a humidified atmosphere of $5 \% \mathrm{CO}_{2}$ and $95 \%$ air.

After the maturation culture, the nuclear stage of the oocytes was examined by staining with $1 \%$ aceto-orcein. For controls, oocytes were collected from ovarian early antral $(0.4-0.7 \mathrm{~mm})$ or late antral (3-5 mm) follicles. Their diameters were measured, and their nuclear morphology was then examined. Furthermore, some oocytes isolated from early antral $(0.4-0.7 \mathrm{~mm})$ or late antral $(3-5 \mathrm{~mm})$ follicles were subjected to maturation culture and their nuclear stage was also examined.

\section{In vitro fertilization}

Frozen bovine spermatozoa were thawed in water at $38.5 \mathrm{C}$ and suspended in fertilization medium (IVF100; Research Institute for the Functional Peptides, Yamagata, Japan). Spermatozoa were washed twice in this medium and then introduced into 100- $\mu 1$ drops of fertilization medium containing $10 \mathrm{mg} / \mathrm{ml}$ BSA, 10 $\mu \mathrm{g} / \mathrm{ml}$ heparin (Novo Heparin, Novo Nordisk Pharma Ltd., A/S, Denmark), and $5 \mathrm{mM}$ 
theophylline to give a final concentration of $5 \times 10^{6}$ spermatozoa/ml. The cumulus cell-enclosed oocytes grown in vitro were placed into droplets within which the spermatozoa were suspended, and co-cultured for $5 \mathrm{~h}$ at $38.5 \mathrm{C}$ in a humidified atmosphere of $5 \% \mathrm{CO}_{2}$ and $95 \%$ air. The oocytes were then denuded and washed several times in development medium (IVD101; Research Institute for the Functional Peptides). The denuded oocytes were transferred into $500 \mu \mathrm{l}$ of the development medium. After $10-12 \mathrm{~h}$, some oocytes were mounted onto slides, fixed, stained with $1 \%$ acetoorcein and examined under a differential interference microscope to check for sperm penetration of the oocytes. Oocytes with a sperm head or male pronucleus and a corresponding sperm tail in the ooplasm were judged to be penetrated. Penetrated oocytes were categorized as having normal or polyspermic fertilization according to the number of pronuclei and sperm heads in the ooplasm. The other inseminated oocytes were further cultured for up to 8 days. Cleavage of the embryos was checked after $48 \mathrm{~h}$ and 72-96 h, and the developmental competence of reaching the blastocyst stage was examined after 8 days. As a control, fully grown oocytes collected from ovarian large antral follicles $(3-5 \mathrm{~mm})$ were cultured, inseminated, and examined in the same manner.

\section{Statistical analysis}

Statistical differences in the mean diameters of the oocytes were analyzed by the Student's $t$-test. Other values were analyzed by the $\chi^{2}$ test with Yates' correction for continuity. A probability of less than 0.05 was considered significant.

\section{Results}

Early antral follicles $0.4-0.7 \mathrm{~mm}$ in diameter contained growing oocytes about $95 \mu \mathrm{m}$ in diameter, and large antral follicles 3-5 mm contained fully-grown oocytes about $120 \mu \mathrm{m}$ in diameter (Table 1). All oocytes in early antral follicles $0.4-0.7 \mathrm{~mm}$ in diameter immediately after collection from bovine ovaries were arrested at the germinal vesicle stage (GV) with decondensed filamentous or stringy chromatin distributed throughout the germinal vesicle. After maturation culture, all the oocytes were arrested at the GV stage, except for one degenerated oocyte. When oocytes grown in vivo from 3-5 mm follicles were subjected to maturation culture, 90\% (62/69) underwent germinal vesicle breakdown and $77 \%$ (53/69) matured to MII. Small oocytes, which were contained in early antral follicles and incapable of resuming meiosis, were cultured in serum-free medium for 16 days. Of the 76 oocytes subjected to growth culture, 56 (74\%) were morphologically normal and enclosed by cumulus granulosa cells

Table 1. Growth and maturational competence of bovine oocytes grown in serum-free medium

\begin{tabular}{|c|c|c|c|c|c|c|c|c|c|c|c|c|}
\hline \multirow{3}{*}{$\begin{array}{l}\text { Follicular } \\
\text { diameter }^{1)}\end{array}$} & \multirow{2}{*}{\multicolumn{2}{|c|}{$\begin{array}{c}\text { Culture } \\
\text { methods }{ }^{2)}\end{array}$}} & \multirow{3}{*}{$\begin{array}{c}\text { No. of } \\
\text { oocytes } \\
\text { examined }\end{array}$} & \multirow{3}{*}{$\begin{array}{c}\text { Mean diameter } \\
\text { of oocytes }{ }^{3)} \\
(\mu \mathrm{m} \pm \mathrm{SD})\end{array}$} & \multicolumn{7}{|c|}{ Nuclear morphology of surviving oocytes ${ }^{4}(\%)$} & \multirow{3}{*}{$\begin{array}{c}\text { No. }(\%) \text { of } \\
\text { oocytes } \\
\text { degenerating }\end{array}$} \\
\hline & & & & & \multirow{2}{*}{$\mathrm{GV}$} & \multicolumn{6}{|c|}{ GVBD } & \\
\hline & IVG & IVM & & & & & tal & $\mathrm{D}$ & MI & MII & Abnormal & \\
\hline $0.4-0.7 \mathrm{mr}$ & - & - & 76 & $94.8 \pm 2.6^{\mathrm{a}}$ & $76(100)$ & 0 & (0) & $0(0)$ & $0 \quad(0)$ & $0(0)$ & $0(0$ & $0(0)$ \\
\hline $0.4-0.7 \mathrm{~mm}$ & - & + & 26 & $94.3 \pm 2.7^{\mathrm{a}}$ & $25(96)^{\mathrm{a}}$ & 0 & $(0)$ & $0(0)$ & $0 \quad(0)$ & $0(0)$ & $0(0)$ & $1(4)$ \\
\hline $0.4-0.7 \mathrm{~mm}$ & + & + & 56 & $111.5 \pm 4.9^{\mathrm{b}}$ & $2(3)^{b}$ & 47 & $(84)^{\mathrm{a}}$ & $0(0)$ & $27(48)^{\mathrm{a}}$ & $20(36)^{a}$ & $0(0)$ & 7 (13) \\
\hline $3-5 \mathrm{~mm}$ & - & - & 65 & $120.5 \pm 4.1^{\mathrm{c}}$ & $63(97)^{b}$ & 2 & $(3)^{b}$ & $1(2)$ & $1(2)^{b}$ & $0(0)$ & $0(0)$ & $0(0)$ \\
\hline $3-5 \mathrm{~mm}$ & - & + & 69 & $120.8 \pm 5.2^{c}$ & $3(4)^{b}$ & 62 & $(90)^{\mathrm{a}}$ & $1(1)$ & $6(9)^{b}$ & $53(77)^{\mathrm{b}}$ & $2(3)$ & $4(6)$ \\
\hline
\end{tabular}

1) Bovine oocytes were collected from follicles of 0.4-0.7 $\mathrm{mm}$ and $3-5 \mathrm{~mm}$ in diameter.

2) Early antral follicles were embedded in collagen gels and cultured in serum-free medium for 16 days. After growth culture, cumulus cell-enclosed oocytes were transferred into maturation medium containing $0.1 \mathrm{mg} / \mathrm{ml}$ sodium pyruvate and $10 \%$ fetal calf serum for $24 \mathrm{~h}$, and then examined.

3) The diameters of the oocytes (excluding the zona pellucida) were measured before IVM, and those of oocytes which were not subjected to IVM were measured just after recovery from follicles.

4) GV: Germinal vesicle stage. GVBD: germinal vesicle breakdown. GVBD oocytes were classified as D, MI, MII and Abnormal. D: diakinesis stage, MI: The first metaphase, MII: The second metaphase, Abnormal: chromosomes were scattered in cytoplasm.

a-c Values with different superscripts in the same column differ significantly $(\mathrm{P}<0.05)$. 

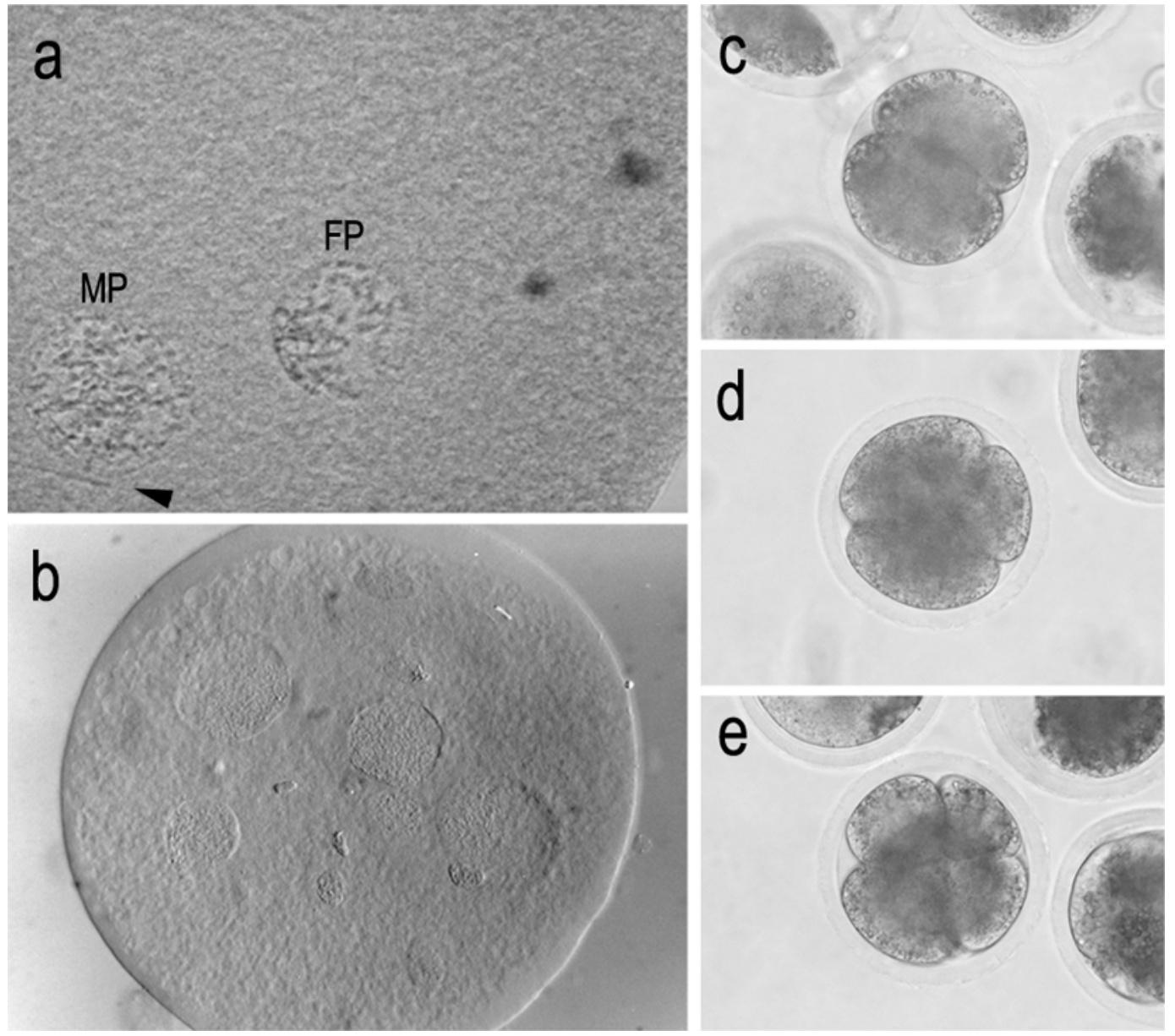

Fig. 1. Bovine oocytes grown in serum-free medium were subjected to maturation culture and inseminated with spermatozoa. After 10-12 h, penetrated oocytes formed a female and a male pronuclei (a) with a sperm tail corresponding to the male pronucleus (an arrow head). Some abnormally penetrated oocytes contained multiple pronuclei and enlarged sperm heads (b). Oocytes had cleaved and developed to the 2-cell stage after $48 \mathrm{~h}$ (c), and 4-cell (d) and 5-8-cell embryos (e) were observed after 3-4 days.

after growth culture. The mean diameter after growth culture significantly increased compared to that before culture (Table 1, before: $94.8 \pm 2.6 \mu \mathrm{m}$, after: $111.5 \pm 4.9 \mu \mathrm{m})$. Furthermore, $36 \%(20 / 56)$ of the oocytes reached MII after subsequent maturation culture.

Bovine oocytes grown in serum-free medium were subjected to maturation culture and inseminated with spermatozoa. Of the 145 oocytes, $18(12 \%)$ formed a female and a male pronuclei (Fig. 1a), and $10(7 \%)$ had a female pronucleus and an enlarged sperm head (Table 2). Among abnormally penetrated oocytes, 10 were penetrated by multiple spermatozoa (10 or more spermatozoa/oocyte, Fig. 1b) and 3 were penetrated by a spermatozoon at the MI stage. In contrast, 58\% (40/69) of oocytes grown in vivo formed a female and a male pronuclei and $2(3 / 69)$ had a female pronucleus and an enlarged sperm head. Oocytes abnormally penetrated by multiple spermatozoa were also observed in the group grown in vivo, but the oocytes formed a female pronucleus and at most 3 male pronuclei.

Next, 106 bovine oocytes grown in serum-free medium were inseminated, and their developmental competence was examined (Table 3). Nine ( $8 \%$ ) oocytes cleaved and developed to the 2-cell stage (Fig. 1c) $48 \mathrm{~h}$ after insemination. After 
Table 2. In vitro fertilization of bovine oocytes grown in serum-free medium

\begin{tabular}{|c|c|c|c|c|c|c|c|c|c|c|c|}
\hline \multirow{3}{*}{$\begin{array}{l}\text { Oocyte } \\
\text { growth }{ }^{1)}\end{array}$} & \multirow{3}{*}{$\begin{array}{c}\text { No. of } \\
\text { oocytes } \\
\text { inseminated }\end{array}$} & \multirow{3}{*}{$\begin{array}{c}\text { Mean diameter } \\
\text { of oocytes } \\
(\mu \mathrm{m} \pm \mathrm{SD})\end{array}$} & \multirow{2}{*}{\multicolumn{4}{|c|}{$\begin{array}{c}\text { No. }(\%) \text { of } \\
\text { non-penetrated oocytes }{ }^{2)}\end{array}$}} & \multicolumn{4}{|c|}{ No. (\%) of penetrated oocytes ${ }^{3)}$} & \multirow{3}{*}{$\begin{array}{c}\text { No. }(\%) \text { of } \\
\text { oocytes } \\
\text { degenerating }\end{array}$} \\
\hline & & & & & & & \multirow[b]{2}{*}{$\mathrm{FP}+\mathrm{SH}$} & \multirow[b]{2}{*}{$\mathrm{FP}+\mathrm{MP}$} & \multirow{2}{*}{$\begin{array}{l}\text { Poly- } \\
\text { spermy }\end{array}$} & \multirow{2}{*}{$\begin{array}{c}\text { Penetration } \\
\text { at MI }\end{array}$} & \\
\hline & & & $\mathrm{GV}$ & MI & MII & Abnormal & & & & & \\
\hline in vivo & 69 & $120.8 \pm 2.9^{a}$ & $0(0)$ & $8(12)^{\mathrm{a}}$ & $4(6)$ & $0(0)$ & $2(3)$ & $40(58)^{\mathrm{a}}$ & $10(15)$ & $0(0)$ & $5(7)$ \\
\hline in vitro & 145 & $115.3 \pm 3.9^{b}$ & $1(1)$ & $54(37)^{\mathrm{b}}$ & 19 (13) & $20(14)$ & $10(7)$ & $18(12)^{\mathrm{b}}$ & $10(7)$ & $3(2)$ & $10(7)$ \\
\hline
\end{tabular}

1) Bovine oocytes in follicles 3-5 mm in diameter were matured for $24 \mathrm{~h}$, and inseminated with frozen-thawed bovine spermatozoa (in vivo). Bovine oocytes in early antral follicles $0.4-0.7 \mathrm{~mm}$ in diameter were cultured in serum-free medium for 16 days. Oocytes grown in vitro were matured for $24 \mathrm{~h}$, and subsequently inseminated with frozen-thawed bovine spermatozoa (in vitro). In both groups, oocytes were fixed, stained and examined 10-12 h after insemination.

2) GV: Germinal vesicle stage, MI: The first metaphase, MII: The second metaphase, Abnormal: chromosomes were scattered in cytoplasm.

3) FP+SH: Oocytes had a female pronucleus and an enlarged sperm head. FP+MP: Oocytes had a female and a male pronucleus. Polyspermy: MII oocytes penetrated by multiple spermatozoa. Penetration at MI: MI oocytes penetrated by spermatozoa.

a,b Values with different superscripts in the same column differ significantly $(\mathrm{P}<0.05)$.

Table 3. Embryonic development of bovine oocytes grown in serum-free medium

\begin{tabular}{|c|c|c|c|c|c|c|c|c|c|c|c|c|c|}
\hline \multirow{3}{*}{$\begin{array}{l}\text { Oocyte } \\
\text { growth }^{1)}\end{array}$} & \multirow{3}{*}{$\begin{array}{c}\text { No. of } \\
\text { oocytes } \\
\text { inseminated }\end{array}$} & \multicolumn{11}{|c|}{ No. (\%) of cleaved embryos $\left.{ }^{2}\right)$} & \multirow{3}{*}{$\begin{array}{c}\text { No. (\%) of } \\
\text { blastocysts }\end{array}$} \\
\hline & & \multicolumn{5}{|c|}{$48 \mathrm{~h}$} & \multicolumn{6}{|c|}{$72-96 \mathrm{~h}$} & \\
\hline & & Total & 2 cell & $3-4$ cell & $5-8$ cell & $9-16$ cell & Total & 2 cell & $3-4$ cell & $5-8$ cell & $9-16$ cell & 16- cell & \\
\hline in vivo & 140 & $82(59)^{a}$ & $10(7)$ & $20(14)$ & $44(31)$ & $8(6)$ & $84(60)^{\mathrm{a}}$ & $5(6)$ & $3(2)$ & $8(6)$ & $22(16)$ & $46(33)$ & $24(17)$ \\
\hline in vitro & 106 & $9(8)^{b}$ & $9(8)$ & $0(0)$ & $0(0)$ & $0(0)$ & $11(11)^{\mathrm{b}}$ & $6(6)$ & $2(0)$ & $3(3)$ & $0(0)$ & $0(0)$ & $0(0)$ \\
\hline
\end{tabular}

1) Bovine oocytes in follicles $3-5 \mathrm{~mm}$ in diameter were matured for $24 \mathrm{~h}$, and inseminated with frozen-thawed bovine spermatozoa (in vivo). Bovine oocytes in early antral follicles $0.4-0.7 \mathrm{~mm}$ in diameter were cultured in serum-free medium for 16 days. Oocytes grown in vitro were matured for $24 \mathrm{~h}$, and subsequently inseminated with frozen-thawed bovine spermatozoa (in vitro).

2) Cleavage of embryos was checked $48 \mathrm{~h}$ and $72-96 \mathrm{~h}$ after insemination, and developmental competence to the blastocyst stage was examined after 8 days.

a,b Values with different superscripts in the same column differ significantly $(\mathrm{P}<0.05)$.

72-96 h, 2 (2\%) had developed to 3-4-cell (Fig. 1d) and $3(3 \%)$ to $5-8$-cell embryos (Fig. 1e), however, no embryos had reached the blastocyst stage after 8 days. In contrast, $59 \%(82 / 140)$ of oocytes grown in vivo cleaved, and more than half $(31 / 59)$ of those had developed to the 5-8-cell stage $48 \mathrm{~h}$ after insemination. After 72-96 h, 33\% (46/140) had developed over 16-cell embryos, and 17\% (24/140) had developed to the blastocyst stage by 8 days.

\section{Discussion}

Several culture systems have been developed to support the growth of small immature oocytes. In early experiments, whole ovaries or cortical slices of ovaries were cultured [12]. As isolation methods for small follicles such as collagenase treatment and micro-dissection using surgical blades improved, culture of whole follicles and oocyte-granulosa cell complexes have been introduced. Although culture systems to make oocytes grow have improved, there have been few reports demonstrating the ability of oocytes grown in vitro to mature and be fertilized. We previously cultured bovine whole antral follicles containing growing immature oocytes in serum-free medium [11]. In that experiment, the oocytes cultured for 16 days survived and grew to nearly full size (about $120 \mu \mathrm{m}$ ) with the oocytes enclosed by granulosa cells, and some acquired maturational competence. In the present study, we examined the fertilization competence of the oocytes grown in serum-free medium, and found that the oocytes could be fertilized and cleaved, but did not develop to the blastocyst stage.

As mammalian oocytes approach the end of their growth phase, they acquire the competence to 
undergo nuclear maturation to prepare the egg, and cytoplasmic maturation to prepare the egg for development [13 (reviewed by Eppig)]. Nuclear maturation reflects the progression of chromatin morphology from the GV stage to MII. Cytoplasmic maturation reflects changes in the distribution and organization of ooplasmic organelles for later oocyte activation and preimplantational development. Fully grown oocytes in large antral follicles undergo meiotic resumption and progress to MII [14, 15], while meiotically incompetent oocytes in small antral follicles are not able to resume meiosis [16-18]. Therefore, some of the oocytes grown in the present study are thought to have acquired nuclear maturation competence during their growth in serum-free medium. However, after IVF oocytes cleaved but did not develop to the blastocyst stage, indicating that their cytoplasmic maturation was incomplete.

The ability to develop to the blastocyst stage is one of the important indicators of the completion of cytoplasmic maturation. During the growth phase, oocytes synthesize and accumulate mRNA, proteins, and organelles, which constitute the maternal contribution to oocyte activation, fertilization, and pre-implantational development. In fact, bovine oocytes that do not complete cytoplasmic maturation fail to develop to the blastocyst stage in in vitro embryo production systems [19-21]. Therefore, synthesis and accumulation of various substances during oocyte growth are indispensable to the success of embryo development to the blastocyst stage. In the present study, oocytes grew in serum-free medium scarcer in nutrition, gonadotropins, and growth factors than serum-supplemented medium. Thus ooplasmic conditions for early embryonic development were not sufficiently prepared during the growth phase, resulting in failure to progress to the blastocyst stage. In addition, when the penetration status of oocytes grown in vitro after insemination of spermatozoa was checked, some oocytes had multiple male pronuclei and more than two sperm heads. These results indicate that the oocytes were penetrated by multiple spermatozoa. The ability of oocytes to block polyspermy develops during final meiotic maturation [22], which has been experimentally verified by inseminating immature and maturing bovine oocytes under in vitro conditions [23]. These results confirm that the oocytes grown in our culture system did not fully acquire cytoplasmic competence during the growth phase.

The present study demonstrates that bovine oocytes survive and grow within early antral follicles cultured in serum-free medium at a high rate, and that they are able to be fertilized, although they do not acquire full developmental competence. Because various mRNAs and proteins that appear during oocyte growth and maturation are related to fertilization and the early development of post-fertilization, we think that hormones and growth factors influencing the acquisition of maturational and fertilizable competence of bovine oocytes could be clarified using this serum-free culture system.

\section{Acknowledgments}

We would like to thank DVM. Luis G. Villa-Diaz for his careful reading of the manuscript. This work was supported in part by a Grant-in-Aid for Creative Scientific Research (13GS0008) to T. M., and by a 21st Century COE Program to S. S. from the Ministry of Education, Culture, Sports, Science and Technology of Japan.

\section{References}

1. Yamamoto K, Otoi T, Koyama N, Horikita $\mathbf{N}$, Tachikawa S, Miyano T. Development to live young from bovine small oocytes after growth, maturation and fertilization in vitro. Theriogenology 1999; 52: 81-89.

2. Hirao $Y$, Itoh T, Shimizu M, Iga K, Aoyagi K, Kobayashi M, Kacchi M, Hoshi H, Takenouchi N. In vitro growth and development of bovine oocytegranulosa cell complexes on the flat substratum: effects of high polyvinylpyrrolidone concentration in culture medium. Biol Reprod 2004; 70: 83-91.

3. Maurer HR. Towards chemically-defined, serumfree media for mammalian cell culture. In: Freshney RI (ed.), Animal Cell Culture. Oxford: IRL press; 1986: 13-31.

4. Merten OW. Safety issues of animal products used in serum-free media. Dev Biol Stand 1999; 99: 167180. 
5. Figueiredo JR, Hulshof SCJ, Van den Hurk R, Nusgens B, Bevers MM, Ectors FJ, Beckers JF. Preservation of oocyte and granulosa cell morphology in bovine preantral follicles cultured in vitro. Theriogenology 1994; 41: 1333-1346.

6. Hirao Y, Nagai T, Kubo M, Miyano T, Miyake M, Kato S. In vitro growth and maturation of pig oocytes. J Reprod Fertil 1994; 100: 333-339.

7. Cecconi S, Barboni B, Coccia M, Mattioli M. In vitro development of sheep preantral follicles. Biol Reprod 1999; 60: 594-601.

8. Cecconi S, Capacchietti G, Russo V, Berardinelli P, Mattioli M, Barboni B. In vitro growth of preantral follicles isolated from cryopreserved ovine ovarian tissue. Biol Reprod 2004; 70: 12-17.

9. Gutierrez CG, Ralph JH, Telfer EE, Wilmut I, Webb R. Growth and antrum formation of bovine preantral follicles in long-term culture in vitro. Biol Reprod 2000; 62: 1322-1328.

10. Newton H, Picton H, Gosden RG. In vitro growth of oocyte-granulosa cell complexes isolated from cryopreserved ovine tissue. J Reprod Fertil 1999; 115: 141-150.

11. Senbon S, Miyano T. Bovine oocytes in early antral follicles grow in serum-free media: effect of hypoxanthine on follicular morphology and oocyte growth. Zygote 2002; 10: 301-309.

12. Matrtinovitch PN. The development in vitro of the mammalian gonad-Ovary and ovogenesis. Proc Roy Soc B 1938; 125: 232-249.

13. Eppig JJ. Coordination of nuclear and cytoplasmic oocyte maturation in eutherian mammals. Reprod Fertil Dev 1996; 8: 485-489.

14. Pincus G, Enzmann EV. The comparative behavior of mammalian eggs in vivo and in vitro. I. The activation of ovarian eggs. J Exp Med 1935; 62: 655675 .
15. Edwards RG. Maturation in vitro of mouse, sheep, cow, pig, rhesus monkey and human ovarian oocytes. Nature 1965; 208: 349-351.

16. Sorensen RA, Wassarman PM. Relationship between growth and meiotic maturation of the mouse oocyte. Dev Biol 1976; 50: 531-536.

17. Wickramasinghe D, Ebert KM, Albertini DF. Meiotic competence acquisition is associated with the appearance of M-phase characteristics in growing mouse oocytes. Dev Biol 1991; 143: 162-172.

18. De Smedt V, Crozet N, Gall L. Morphological and functional changes accompanying the acquisition of meiotic competence in ovarian goat oocyte. J Exp Zool 1994; 269: 128-139.

19. Pavlok A, Lucas-Hahn A, Niemann H. Fertilization and developmental competence of bovine oocytes derived from different categories of antral follicles. Mol Reprod Dev 1992; 31: 63-67.

20. Pavlok A, Kopecny V, Lucas-Hahn A, Niemann H. Transcriptional activity and nuclear ultrastructure of 8-cell bovine embryos developed by in vitro maturation and fertilization of oocytes from different growth categories of antral follicles. Mol Reprod Dev 1993; 35: 233-243.

21. Lonergan P, Monaghan P, Rizos D, Boland MP, Gordon I. Effect of follicle size on bovine oocyte quality and developmental competence following maturation, fertilization, and culture in vitro. Mol Reprod Dev 1994; 37: 48-53.

22. Ducibella T, Buetow J. Competence to undergo normal, fertilization-induced cortical activation develops after metaphase I of meiosis in mouse oocytes. Dev Biol 1994; 165: 95-104.

23. Niwa K, Park CK, Okuda K. Penetration in vitro of bovine oocytes during maturation by frozen-thawed spermatozoa. J Reprod Fertil 1991; 91: 329-336. 